\title{
Estimation of Certain Physical and Chemical Fruit Characteristics of Various Cherry Laurel (Laurocerasus officinalis Roem.) Genotypes
}

\author{
Ferit Celik \\ Ozalp Vocational School, Yuzuncu Yil University, 65400 Ozalp, Van-Turkey
}

Sezai Ercisli ${ }^{1}$

Department of Horticulture, Agricultural Faculty, Ataturk University, 25240

Erzurum-Turkey

\author{
Suzan O. Yilmaz \\ Department of Food Engineering, Engineering Faculty, Sakarya University, \\ 54040 Sakarya-Turkey
}

\section{Attila Hegedus \\ Department of Genetics and Plant Breeding, Corvinus University of Budapest, 1114 Budapest-Hungary}

Additional index words. Cherry laurel, bioactive content, fruit characteristics, food properties

\begin{abstract}
Fruits of 11 cherry laurel (Laurocerasus officinalis L.) genotypes grown in a single location, Rize province, were analyzed for their fruit characteristics. Both physical and chemical characteristics of cherry laurel fruits were significantly influenced by genotypes. Fruit weight, the number of fruits per cluster, and flesh per seed ratio ranged between 1.87 and $4.01 \mathrm{~g} ; 9.21$ and 21.05, and 5.54 and 9.33, respectively. The genotypes R06 and R09 had the highest total anthocyanin $[205$ and $202 \mathrm{mg} / 100 \mathrm{~g}$ fresh weight (FW), respectively] and R06 and R11 had the highest total phenolic contents $(503$ and $481 \mathrm{mg} / 100 \mathrm{~g} \mathrm{FW}$, respectively). Total carotenoid and vitamin $C$ contents ranged from 207 to $278 \mathrm{mg} / 100 \mathrm{~g}$ FW and 2.1 to $4.1 \mathrm{mg} / 100 \mathrm{~g} \mathrm{FW}$, respectively. Soluble solid content (SSC), crude fiber, crude protein, pectin, ash, and $\mathrm{pH}$ of genotypes fell between $9.64 \%$ and $17.10 \% ; 0.44 \%$ and $0.85 \% ; 1.44 \%$ and $2.09 \% ; 0.20 \%$ and $0.47 \% ; 0.25 \%$ and $0.71 \%$, and 4.30 and 4.93 , respectively. Data demonstrated that the great variations observed in the physical and chemical characteristics of individual cherry laurel genotypes might be explained by genotypic effect because all genotypes grew under the same ecological conditions. The investigated genotypes seemed to be perspective in health promotion.
\end{abstract}

Plant genetic resources for food and agriculture are playing an ever growing role on world food security and economic development. As an integral component of agricultural biodiversity, these resources are crucial to the intensification of sustainable agricultural production and the supply of livelihood for a large population who depend on agriculture (Cohen et al., 1991).

However, currently plant genetic resources are facing with increasing pressure at global, regional, and local levels and are also threatened by it. In fact, these plants are the raw materials to improve the ability of crops to respond to climate changes and hence they must be protected. An enhanced use of plant genetic diversity is essential to address these and other future challenges (Malik and Singh, 2006).

Received for publication 30 Mar. 2011. Accepted for publication 20 Apr. 2011.

${ }^{1}$ To whom reprint requests should be addressed; e-mail sercisli@hotmail.com. temperate growing regions. The two main groups of cherries, sweet and sour cherries, are reported to have originated in an area that includes Asia Minor, Iran, Iraq, and Syria (Vavilov, 1951).

Cherry laurel (Laurocerasus officinalis), locally known as 'Taflan' or 'Karayemis' is a popular fruit among local people and abundantly distributed in the Black Sea Region (Alasalvar et al., 2005) in Turkey, both occurring in near forest populations and hedgerows around gardens. The species is still among the less known fruits and is very adaptable to marginal environments where the most fragile groups live and they represent a source of food of particular significance for local peoples (Karadeniz and Kalkisim, 1996). The high morphological diversity among cherry laurel trees is visible in the region (Beyhan, 2010; Karadeniz and Kalkisim, 1996). Therefore sustainable use of this species and its conservation are essential.

The fruits of cherry laurel are consumed fresh or dried or processed into jam, marmalade, canned, or pickled (Beyhan, 2010) and its importance is not limited to its nutritive value but also their high contents of potentially health-promoting components (Alasalvar et al., 2005; Orhan and Akkol, 2011; Ustun and Tosun, 2003). Cherry laurel fruits and seeds have been used as traditional medicines for a long time in Turkey, as well (Baytop, 2004). It is also connected to the heritage of cultural values in the region.

More recently, strong competition and consumers' expectations in the food sector forced food producers to create new products with high sensory attractiveness and health-promoting properties. They often use less-known fruits because of their health-promoting characteristics due to the high contents of vitamins and antioxidants.

Only few reports have been published on the bioactive contents of cherry laurel genotypes sampled in the West Black Sea Region. However, reports from the area of the diversity center, namely the Eastern Black Sea Region, are not available. Therefore, the aim of this study was to determine the characteristic physical and chemical parameters of a number of cherry laurel genotypes growing in the Eastern Black Sea Region in Turkey.

\section{Materials and Methods}

as one of the most important diversity centers for cherries. Among 30 cherry taxa, Prunus avium, $P$. cerasus, $P$. mahaleb, Laurocerasus officinalis, $P$. prostrata, $P$. brachypetala, $P$. incana, $P$. angustifolia, $P$. hippophaeoides, and $P$. microcarpa are native to Turkey. Among them, only P. avium and P. cerasus have gained commercial value in Turkey, but $P$. mahaleb and L. officinalis are also important locally (Ercisli, 2004). P. avium, P. cerasus, Laurocerasus officinalis, and $P$. mahaleb are belongs to subgenus Cerasus. $P$. avium and $P$. cerasus are placed in section Eurocerasus, however, L. officinalis belongs to section Laurocerasus and $P$. mahaleb belongs to section Mahaleb (Turkoglu et al., 2010).

Cherries have been valued since ancient times as one of the first tree fruits to ripe in
The study was conducted in Rize province in Eastern Black Sea Region in Turkey. The mean annual temperature and precipitation in Rize were $14{ }^{\circ} \mathrm{C}$ and $2300 \mathrm{~mm}$, respectively. The average humidity is about $75 \%$. The soils of Rize are acidic character $(\mathrm{pH}$ between 4.0 and 4.5) and yellow red podsol (Anonymous, 2010). A total of 11 native cherry laurel (Laurocerasus officinalis) genotypes were preselected in 2009 based on their better yield and fruit chracteristics in natural growing places. The physical and chemical analyses encompassed 50 randomly chosen mature fruits per genotype. The determined parameters included fruit weight, number of fruits per cluster, fruit shape index (width/length), flesh 
per seed ratio, fruit skin color (as chroma, color intensity), SSC, vitamin $\mathrm{C}$, titratable acidity, $\mathrm{pH}$, total fiber, total protein, pectin, ash, total anthocyanin, total carotenoid, total phenol, and antioxidant activity.

Fruit weight was measured by using a digital balance with a sensitivity of $0.001 \mathrm{~g}$. Flesh per seed ratio were counted considering fruit and seed weights. Fruit shape index were counted by the fruit width per length ratio. Skin color (color intensity, Chroma, and lightness, L of cherry laurel fruits was measured on the cheek area of 25 fruits with a Minolta Chroma Meter CR-400 (MinoltaKonica, Japan). Minolta $a^{*}$ and $b^{*}$ values were used to compute values for chroma. Soluble solid contents were determined by extracting and mixing one drop of juice from each fruit into a digital refractometer and displayed as \%. Vitamin $\mathrm{C}$ and titratable acidity were determined with the reflectometer set of Merck Co (Merck RQflex). Crude fiber, ash, and $\mathrm{pH}$ were determined according to methods of the Association of Official Analytical Chemists (AOAC, 1990). Pectin's content in cherry laurel fruits was determined according to the method described by King (1987). Total protein quantity was calculated by multiplying the nitrogen content using Kjeldahl method by the coefficient 6.25 (AOAC, 1990).

For extraction, fruit homogenates obtained with a blender were extracted with acetone, water, and acetic acid (70:29.5:0.5, $\mathrm{v} / \mathrm{v} / \mathrm{v}$ ) for $1 \mathrm{~h}$ in darkness (Singleton and Rossi, 1965). This extract was filtered and used for phytochemical analysis.

Total anthocyanin content was measured with the $\mathrm{pH}$ differential absorbance method as described by Cheng and Breen (1991). Briefly, absorbance of the extract was measured at 510 and $700 \mathrm{~nm}$ in buffers at $\mathrm{pH}$ 1.0 (hydrochloric acid-potassium chloride, $0.2 \mathrm{M}$ ) and 4.5 (acetate acid-sodium acetate, $1 \mathrm{M})$. Anthocyanin content was calculated using a molar extinction coefficient of 26,900 (cyanidin-3-glucoside) and absorbance of $\mathrm{A}=$ $\left[\left(\mathrm{A}_{510}-\mathrm{A}_{700}\right)_{\mathrm{pH} 1.0}-\left(\mathrm{A}_{510}-\mathrm{A}_{700}\right)_{\mathrm{pH}} 4.5\right]$. Results were expressed as milligram cyanidin-3-glucoside equivalents per $100 \mathrm{~g} \mathrm{FW}$.

Total phenolics in the extracts were determined colorimetrically using Folin-Ciocalteu reagent as described by Slinkard and Singleton (1977). Gallic acid was used as a standard and results were expressed as milligram gallic acid equivalents (GAE) per $100 \mathrm{~g} \mathrm{FW}$.

Antioxidant activity was determined spectrophotometrically, according to Wang et al. (1996), as the percent of 2,2-diphenyl-1picrylhydrazyl activity inhibition in fruit flesh extract. The results were expressed as micromole Trolox equivalent per gram FW.

Total carotenoids were extracted according to the method of Talcott and Howard (1999), and measured at $470 \mathrm{~nm}$ wavelength using spectrophotometer, and calculated according to the method of Gross (1991). The results were expressed milligram per $100 \mathrm{~g} \mathrm{FW}$.

The experiment was a completely randomized design with five replications. Data were subjected to analysis of variance and means were separated by Duncan multiple range test at $P<0.01$ significant level. Relationship between bioactive substances and antioxidant activity was determined by correlation analysis (SAS Institute, 2005).

\section{Results and Discussion}

In this study, we found considerable variations in all physical and chemical characteristics among cherry laurel genotypes at $P<0.01$ level (Tables 1-3). The average values of the determined parameters of genotypes are given in the tables.

Fruit weight, the number of fruit per cluster, shape index, and flesh per seed ratio of cherry laurel genotypes ranged from 1.87 $\mathrm{g}$ (R03) to $4.01 \mathrm{~g}$ (R06); 9.21 (R08) to 21.05 (R11); 0.90 (R07) to 1.12 (R01), and 5.54 (R09) to 9.92 (R07), respectively (Table 1). Chroma values of cherry laurel fruit skins fell between 7.72 (R02) and 20.40 (R06) (Table 1). Only a limited number of studies on the physical characteristics of cherry laurel genotypes grown in different parts of Turkey have been published (Akbulut et al., 2007; Beyhan, 2010; Bostan and Islam, 2003; Karadeniz and Kalkisim, 1996; Islam, 2002). In these studies, the average fruit weight, the number of fruits per cluster, shape index, and flesh per seed ratio changed between 1.08 and $6.79 \mathrm{~g} ; 3.60$ and $27.00 ; 0.84$ and 1.25 , and 3.13 and 16.52 , respectively, indicating high variations among cherry laurel genotypes. Our findings are in accordance with those of other studies. Akbulut et al. (2007) reported that the

Table 1. Fruit morphological characteristics of 11 selected cherry laurel (Laurocerasus officinalis L.) genotypes.

\begin{tabular}{lccccccc}
\hline & $\begin{array}{c}\text { Fruit } \\
\text { wt }(\mathrm{g})\end{array}$ & $\begin{array}{c}\text { Number of } \\
\text { fruit per } \\
\text { cluster }\end{array}$ & $\begin{array}{c}\text { Cluster } \\
\text { wt }(\mathrm{g})\end{array}$ & $\begin{array}{c}\text { Shape } \\
\text { index }\end{array}$ & $\begin{array}{c}\text { Flesh/seed } \\
\text { ratio }(\%)\end{array}$ & $\begin{array}{c}\text { Skin color } \\
\text { lightness } \\
(\mathrm{L})\end{array}$ & $\begin{array}{c}\text { Skin color } \\
\text { intensity } \\
\text { (Chroma) }\end{array}$ \\
\hline RZ1 & $2.80 \mathrm{~d}$ & $18.40 \mathrm{abc}$ & $51.52 \mathrm{c}$ & $1.12 \mathrm{a}$ & $9.33 \mathrm{a}$ & $17.33 \mathrm{~d}$ & $8.66 \mathrm{f}$ \\
RZ2 & $3.15 \mathrm{c}$ & $12.16 \mathrm{~d}$ & $38.30 \mathrm{e}$ & $1.02 \mathrm{bc}$ & $7.88 \mathrm{bc}$ & $21.17 \mathrm{~b}$ & $7.72 \mathrm{~g}$ \\
RZ3 & $1.87 \mathrm{~g}$ & $11.40 \mathrm{~d}$ & $21.32 \mathrm{~g}$ & $0.96 \mathrm{cde}$ & $6.68 \mathrm{~d}$ & $18.68 \mathrm{~cd}$ & $14.36 \mathrm{c}$ \\
RZ4 & $1.96 \mathrm{fg}$ & $20.36 \mathrm{ab}$ & $39.91 \mathrm{de}$ & $1.10 \mathrm{a}$ & $7.84 \mathrm{bc}$ & $18.05 \mathrm{~cd}$ & $12.10 \mathrm{e}$ \\
RZ5 & $2.94 \mathrm{~d}$ & $14.94 \mathrm{bcd}$ & $43.92 \mathrm{~d}$ & $1.04 \mathrm{~b}$ & $7.35 \mathrm{~cd}$ & $20.13 \mathrm{bc}$ & $15.58 \mathrm{~b}$ \\
RZ6 & $4.01 \mathrm{a}$ & $16.71 \mathrm{abcd}$ & $67.00 \mathrm{~b}$ & $0.91 \mathrm{e}$ & $8.35 \mathrm{~b}$ & $22.40 \mathrm{a}$ & $20.40 \mathrm{a}$ \\
RZ7 & $3.67 \mathrm{~b}$ & $20.10 \mathrm{ab}$ & $73.77 \mathrm{a}$ & $0.90 \mathrm{e}$ & $9.92 \mathrm{a}$ & $17.66 \mathrm{~d}$ & $15.40 \mathrm{~b}$ \\
RZ8 & $3.21 \mathrm{c}$ & $13.21 \mathrm{~cd}$ & $42.40 \mathrm{de}$ & $1.00 \mathrm{bcd}$ & $7.13 \mathrm{~cd}$ & $19.56 \mathrm{c}$ & $14.20 \mathrm{c}$ \\
RZ9 & $2.16 \mathrm{f}$ & $16.19 \mathrm{abcd}$ & $34.97 \mathrm{ef}$ & $1.03 \mathrm{bc}$ & $5.54 \mathrm{e}$ & $21.19 \mathrm{~b}$ & $13.30 \mathrm{~d}$ \\
RZ10 & $2.44 \mathrm{e}$ & $13.10 \mathrm{~cd}$ & $31.96 \mathrm{f}$ & $0.97 \mathrm{cde}$ & $6.97 \mathrm{~cd}$ & $22.48 \mathrm{a}$ & $12.00 \mathrm{e}$ \\
RZ11 & $2.37 \mathrm{e}$ & $21.05 \mathrm{a}$ & $49.89 \mathrm{~cd}$ & $0.93 \mathrm{de}$ & $7.18 \mathrm{~cd}$ & $21.04 \mathrm{~b}$ & $12.40 \mathrm{e}$ \\
\hline
\end{tabular}

Values in the same column with different lower-case letters are significantly different at $P<0.01$.

Table 2. Fruit chemical characteristics of 11 selected cherry laurel (Laurocerasus officinalis L.) genotypes.

\begin{tabular}{llllllll}
\hline Genotypes & $\begin{array}{c}\text { Crude } \\
\text { fiber }(\%)\end{array}$ & Pectin $(\%)$ & Ash $(\%)$ & SSC $(\%)$ & pH & $\begin{array}{c}\text { Acidity } \\
(\%)\end{array}$ & $\begin{array}{c}\text { Protein } \\
(\%)\end{array}$ \\
\hline RZ-1 & $0.51 \mathrm{cde}$ & $0.28 \mathrm{~cd}$ & $0.62 \mathrm{~b}$ & $10.70 \mathrm{f}$ & $4.41 \mathrm{efg}$ & $0.27 \mathrm{e}$ & $1.99 \mathrm{~b}$ \\
RZ-2 & $0.56 \mathrm{c}$ & $0.30 \mathrm{c}$ & $0.47 \mathrm{~d}$ & $9.64 \mathrm{~h}$ & $4.93 \mathrm{a}$ & $0.70 \mathrm{a}$ & $1.69 \mathrm{de}$ \\
RZ-3 & $0.61 \mathrm{~b}$ & $0.35 \mathrm{~b}$ & $0.55 \mathrm{c}$ & $10.20 \mathrm{~g}$ & $4.37 \mathrm{fg}$ & $0.31 \mathrm{de}$ & $1.86 \mathrm{c}$ \\
RZ-4 & $0.51 \mathrm{cde}$ & $0.27 \mathrm{cde}$ & $0.38 \mathrm{e}$ & $11.07 \mathrm{f}$ & $4.51 \mathrm{de}$ & $0.42 \mathrm{c}$ & $1.47 \mathrm{~h}$ \\
RZ-5 & $0.45 \mathrm{ef}$ & $0.22 \mathrm{ef}$ & $0.28 \mathrm{fg}$ & $14.15 \mathrm{~d}$ & $4.63 \mathrm{c}$ & $0.60 \mathrm{~b}$ & $1.35 \mathrm{~g}$ \\
RZ-6 & $0.44 \mathrm{f}$ & $0.20 \mathrm{f}$ & $0.71 \mathrm{a}$ & $17.10 \mathrm{a}$ & $4.38 \mathrm{efg}$ & $0.28 \mathrm{e}$ & $2.09 \mathrm{a}$ \\
RZ-7 & $0.85 \mathrm{a}$ & $0.42 \mathrm{a}$ & $0.51 \mathrm{~cd}$ & $14.20 \mathrm{~d}$ & $4.45 \mathrm{def}$ & $0.41 \mathrm{c}$ & $1.75 \mathrm{~d}$ \\
RZ-8 & $0.54 \mathrm{~cd}$ & $0.30 \mathrm{c}$ & $0.33 \mathrm{f}$ & $13.40 \mathrm{e}$ & $4.30 \mathrm{~g}$ & $0.29 \mathrm{de}$ & $1.44 \mathrm{~h}$ \\
RZ-9 & $0.50 \mathrm{def}$ & $0.23 \mathrm{def}$ & $0.47 \mathrm{~d}$ & $17.02 \mathrm{a}$ & $4.78 \mathrm{~b}$ & $0.62 \mathrm{~b}$ & $1.61 \mathrm{f}$ \\
RZ-10 & $0.64 \mathrm{~b}$ & $0.30 \mathrm{c}$ & $0.28 \mathrm{fg}$ & $15.05 \mathrm{c}$ & $4.55 \mathrm{~cd}$ & $0.55 \mathrm{~b}$ & $1.48 \mathrm{~h}$ \\
RZ-11 & $0.70 \mathrm{~b}$ & $0.37 \mathrm{ab}$ & $0.25 \mathrm{~g}$ & $16.10 \mathrm{~b}$ & $4.47 \mathrm{def}$ & $0.38 \mathrm{~cd}$ & $1.66 \mathrm{ef}$ \\
\hline
\end{tabular}

Values in the same column with different lower-case letters are significantly different at $P<0.01$.

$\mathrm{SSC}=$ Soluble solid content. dominant fruit shape among 28 selected cherry laurel genotypes was classified as roundish (14 genotypes) followed by conical ( 8 genotypes), oblate (3 genotypes), and oval (3 notypes).

higher mean chroma value $(20.40)$ than the rest of the genotypes. The closest genotypes to R06 in terms of chroma value were R05 (15.58) and R07 (15.40). Among all, genotype R02 had the lowest chroma value (7.72) (Table 1). Halilova and Ercisli (2010) reported chen types between 8.39 and 19.07, which supports portant factor in consumer's choice of food products. It is one of the most important pe quality of acceptance by the consumer (Hendry and Houghton, 1996) found out statistically significant differences in the level of SSC, crude fiber, crude protein, (ing (0) assayed genotypes of genotypes varied from $9.64 \%$ to $17.10 \%$; $0.21 \%$ to $0.51 \% ; 1.44 \%$ to $2.09 \% ; 0.20 \%$ to $0.20 \%$ to $0.70 \%$, respectively (Table 2 ).

The genotypes R06, R09, and R011 showed relatively high levels of soluble protein, pectin, ash, $\mathrm{pH}$, and titratable acidity 
solids $(16.10 \%$ to $17.10 \%)$, and genotype R06 had higher crude protein content $(2.09 \%)$. It was noteworthy that vitamin $\mathrm{C}$ content of all cherry laurel genotypes was low $(2.1-4.1 \mathrm{mg} / 100 \mathrm{~g})$.

The SSC and titratable acidity values in cherry laurel types were reported as $8.6 \%$ to $27.0 \%$ and $0.12 \%$ to $1.21 \%$, respectively (Akbulut et al., 2007; Beyhan, 2010; Halilova and Ercisli, 2010; Ustun and Tosun, 2003). We found pectin contents changing between $0.20 \%$ (R06) and $0.47 \%$ (R07). These pectin contents were lower than those reported by Kolayli et al. (2003) and higher than those described by Ustun and Tosun (2003). However, our results are consistent with the data of sweet cherries (0.24-0.54) reported by Facteau (1982). The significant differences described above, are not surprising due to the possible genotypic and/or environment effects. Pectin and fibers are valuable components of food, because of their role in prevention of colon diseases is underlined in medicine (Green, 2001). Baker (1994) and Reiser (1987), suggested that dietary supplementation with pectin may have reduced the levels of serum total cholesterol, decreased low density lipoprotein cholesterol, and moderated the glucose response.

The contents of total protein and ash in cherry laurel fruits were found between $1.35 \%$ (R05) and 2.09\% (R06) and 0.28\% (R05) and $0.71 \%$ (R06), respectively (Table 2 ). Kolayli et al. (2003) reported protein and ash content as $2.1 \%$ and 0.26 in a cherry laurel genotype from Turkey. Ustun and Tosun (2003) also found an average of $0.53 \%$ ash content in cherry laurel. Total protein and ash contents, however, varied depending on the plant part harvested for food, cultivars, maturity, and the growing environment of the plant (Erturk et al., 2006; Mansour et al., 2011).

The total anthocyanins contents of 11 cherry laurel genotypes ranged from 123 to $205 \mathrm{mg}$ expressed as cyanidin-3-glucoside equivalents per $100 \mathrm{~g} \mathrm{FW}$ (Table 3). The genotype seemed to influence the extent of total anthocyanin accumulation in fruits. Total anthocyanin contents of cherry laurel fruits were reported between 123 and $206 \mathrm{mg}$ (Alasalvar et al., 2005; Halilova and Ercisli, 2010). The total anthocyanin contents of dark-colored sweet cherries were found between $82-298 \mathrm{mg} / 100 \mathrm{~g}$ among cultivars (Duthie et al., 2003). Our results were within these ranges and it can be concluded that besides other fruits cherry laurel might be also a good source of anthocyanins.

Anthocyanin pigments are responsible for the red-purple to blue colors of many fruits, vegetables, and grains. They are water soluble and have been used as natural food colorants for a long time, and, therefore, are regarded as safe substances (Bordignon-Luiz et al., 2007; Potter and Hotchkiss, 1997). Anthocyanins have not only nontoxic and nonmutagenic properties but also positive therapeutic properties, such as antioxidant, anti-inflammatory, anticarcinogenic, antiviral, and antibacterial effects (Tall et al., 2004).

Table 3. Fruit bioactive characteristics of 11 selected cherry laurel (Laurocerasus officinalis L.) genotypes.

\begin{tabular}{lccccc}
\hline & $\begin{array}{c}\text { Total } \\
\text { anthocyanin } \\
(\mathrm{mg} / 100 \mathrm{~g})\end{array}$ & $\begin{array}{c}\text { Total phenolic } \\
\text { content }(\mathrm{mg} \\
\text { GAE/100 g FW })\end{array}$ & $\begin{array}{c}\text { Total carotenoid } \\
\text { content }(\mathrm{mg} / 100 \\
\mathrm{g} \mathrm{FW})\end{array}$ & $\begin{array}{c}\text { Vitamin C } \\
(\mathrm{mg} / 100 \mathrm{~g})\end{array}$ & $\begin{array}{c}\text { DPPH }(\mu \mathrm{mol} \\
\text { Trolox/g FW })\end{array}$ \\
\hline RZ1 & $143 \mathrm{e}$ & $415 \mathrm{de}$ & $211 \mathrm{f}$ & $4.4 \mathrm{ab}$ & $23.1 \mathrm{de}$ \\
RZ2 & $123 \mathrm{f}$ & $364 \mathrm{f}$ & $207 \mathrm{f}$ & $3.7 \mathrm{~b}$ & $21.2 \mathrm{e}$ \\
RZ3 & $167 \mathrm{bc}$ & $450 \mathrm{cde}$ & $243 \mathrm{~cd}$ & $5.2 \mathrm{ab}$ & $28.4 \mathrm{abc}$ \\
RZ4 & $145 \mathrm{de}$ & $418 \mathrm{de}$ & $224 \mathrm{e}$ & $4.8 \mathrm{ab}$ & $24.1 \mathrm{cde}$ \\
RZ5 & $174 \mathrm{~b}$ & $462 \mathrm{bcd}$ & $239 \mathrm{~cd}$ & $5.4 \mathrm{ab}$ & $28.0 \mathrm{abcd}$ \\
RZ6 & $205 \mathrm{a}$ & $503 \mathrm{a}$ & $278 \mathrm{a}$ & $6.8 \mathrm{a}$ & $32.2 \mathrm{a}$ \\
RZ7 & $157 \mathrm{~cd}$ & $440 \mathrm{cde}$ & $230 \mathrm{de}$ & $5.0 \mathrm{ab}$ & $25.4 \mathrm{bcde}$ \\
RZ8 & $142 \mathrm{e}$ & $402 \mathrm{ef}$ & $208 \mathrm{f}$ & $4.2 \mathrm{ab}$ & $22.4 \mathrm{e}$ \\
RZ9 & $202 \mathrm{a}$ & $481 \mathrm{bc}$ & $274 \mathrm{a}$ & $6.4 \mathrm{ab}$ & $29.5 \mathrm{ab}$ \\
RZ10 & $172 \mathrm{~b}$ & $473 \mathrm{bc}$ & $245 \mathrm{c}$ & $6.2 \mathrm{ab}$ & $29.1 \mathrm{ab}$ \\
RZ11 & $197 \mathrm{a}$ & $496 \mathrm{~b}$ & $260 \mathrm{~b}$ & $5.7 \mathrm{ab}$ & $30.3 \mathrm{ab}$ \\
\hline
\end{tabular}

Values in the same column with different lower-case letters are significantly different at $P<0.01$. $\mathrm{GAE}=$ gallic acid equivalent; FW = fresh weight; $\mathrm{DPPH}=$ 2,2-diphenyl-1-picrylhydrazyl.

In this experiment, the total carotenoid contents were greatly different among the cherry laurel genotypes and varied from 207 to $278 \mathrm{mg}$ per $100 \mathrm{~g} \mathrm{FW}$ (Table 3). Results obtained for cherry laurel genotypes indicate that cherry laurel fruits are also a good source of carotenoids, not only anthocyanin. Alasalvar et al. (2005) reported total carotenoid content between 250 and $261 \mathrm{mg}$ among two cherry laurel genotypes in Turkey. Our data are in agreement with the reported carotenoid contents. Carotenoids are the most widely distributed group of pigments naturally accumulating in large quantities and are known for their structural diversity and various functions including the brilliant red, orange, and yellow colors of edible fruits (Socaciu, 2008). Many fruit and vegetable crops have high concentrations of carotenoid compounds. Carotenoids are known to have antioxidant activity by quenching free radicals and singlet oxygen. The ability of carotenoids to function as antioxidants may contribute to the reduction in disease risk (Tonucci et al., 1995).

The total phenolic contents of cherry laurel genotypes were in the range of 364 to $503 \mathrm{mg}$ GAE per $100 \mathrm{~g}$ fresh fruit. Earlier, a wide variation was observed on total phenolic content in fruits of two cherry laurel genotypes that ranged from 454 to $651 \mathrm{mg}$ ferulic acid equivalents/100 g FW (Alasalvar et al., 2005). The phenolic content and composition of fruits and vegetables depend on the genetic and environmental factors as well as post-harvest processing conditions (Landmark and Alm, 2006). Plant phenolics are the largest class of plant secondary metabolites, which, in many cases, serve in plant defense mechanisms to counteract the reactive oxygen species to survive and prevent molecular damage and damage by microorganisms, insects, and herbivores (Prior et al., 1998).

The antioxidant activity was highly different among cherry laurel genotypes (21.2 to $32.2 \mu \mathrm{mol} \cdot$ Trolox $/ \mathrm{g} \mathrm{FW}$, Table 3 ). The lowest antioxidant activity was observed in genotype R02 as $21.2 \mu \mathrm{mol}$ Trolox/g FW basis and the highest activity was observed in genotype R06 as $32.2 \mu$ mol Trolox/g FW). This parameter is very important from nutritive point of view because cherry laurel fruits are edible when ripe and it is clear that they
Table 4. Correlation coefficients $(r)$ between bioactive compounds in cherry laurel fruits and antioxidant activity (2,2-diphenyl-1picrylhydrazyl).

\begin{tabular}{lc}
\hline Bioactive substances & Antioxidant activity \\
\hline Total carotenoids & $0.843^{* *}$ \\
Total anthocyanins & $0.774^{* *}$ \\
Total phenolics & $0.945^{* *}$ \\
\hline
\end{tabular}

$* * P=0.01$.

are a valuable source of some biologically active compounds, including antioxidants.

We found high positive correlation between antioxidant activity and total carotenoids, total anthocyanins and total phenolic content (Table 4). These relationships show that the antioxidant activity of cherry laurel fruits is closely related to not only anthocyanin and carotenoid contents but also phenolics content. Dark red-colored fruits, which are richer in total anthocyanin, carotenoids, and phenolic compounds, are also very valuable sources of antioxidants (Wang et al., 1996).

The past decade witnessed an increasing demand on less-known crops for various reasons, such as greater food security, healthy nutrition, cultural knowledge, income etc. From this study, it is clear that cherry laurel is an important example of great plant diversity in Turkish. Currently various nongovernmental organizations and governmental projects are under way to declare local species and reintroduce them to farmers and consumers for a sustainable utilization and on-farm conservation in Turkey. This rich genetic potential becomes important to plant breeding programs. Especially, these land races can be used to improve the commercial varieties.

\section{Literature Cited}

Akbulut, M., I. Macit, S. Ercisli, and A. Koc. 2007. Evaluation of 28 cherry laurel (Laurocerasus officinalis) genotypes in the Black Sea region, Turkey. N. Z. J. Crop Hort. Sci. 35(4):463-465.

Alasalvar, C., M. Al-Farsi, and F. Shahidi. 2005. Compositional characteristics and antioxidant components of cherry laurel varieties and pekmez. J. Food Sci. 70:47-52.

Anonymous. 2010. Some climatic data of Rize province in the year between 1970-2010, Turkish 
State Meteorological Service, p. 20-33, Ankara, Turkey [in Turkish].

AOAC. 1990. Official methods of analysis. 15th Ed. Association of Official Analytical Chemists, Washington, DC.

Atik, A.D., M. Oztekin, and F. Erkoc. 2010. Biodiversity and examples of endemic plants in Turkey. J. Gazi Edu. Fac. 30(1):219-240.

Baker, R.A. 1994. Potential dietary benefits of citrus pectin and fiber. Food Technol. 48(11): 133-139.

Baytop, T. 2004. Therapy with medicinal plants in Turkey (past and present), p. 353. Nobel Press, Istanbul.

Beyhan, O. 2010. A study on selection of promising native cherry laurel (Prunus laurocerasus L.) genotypes from Sakarya, Turkey. J. Anim. Plant Sci. 20(4):231-233.

Bordignon-Luiz, M.T., C. Gauche, E.F. Gris, and L.D. Falcao. 2007. Colour stability of anthocyanins from Isabel grapes (Vitis labrusca L.) in model systems. LWT Food Sci. Technol. 40(4):594-599.

Bostan, S.Z. and A. Islam. 2003. Phenological and pomological properties of cherry laurel (Prunus laurocerasus L.) types grown in Trabzon. J. Ondokuz Mayis Univ. 18(1):27-31.

Cheng, G.W. and P.J. Breen. 1991. Activity of phenylalanine ammonialyase (PAL) and concentrations of anthocyanins and phenolics in developing strawberry fruit. J. Amer. Soc. Hort. Sci. 116:865-869.

Cohen, J., J.B. Alcorn, and C.S. Potter. 1991. Utilisation and conservation of genetic resources: International projects for sustainable agriculture. Econ. Bot. 45:190-199.

Duthie, G.G., P.T. Gardner, and J.A.M. Kyle. 2003. Plant polyphenols: Are they the new magic bullet? Proc. Nutr. Soc. 62:559-603.

Ercisli, S. 2004. A short review of the fruit germplasm resources of Turkey. Genet. Resources Crop Evol. 51:419-435.

Erturk, U., C. Mert, and A. Soylu. 2006. Chemical composition of fruits of some important chestnut cultivars. Braz. Arch. Biol. Technol. 49(2): 183-188.

Facteau, T.J. 1982. Relationship of soluble solids, alcohol-insoluble solids, fruit calcium, and pectin levels to firmness and surface pitting in
'Lambert' and 'Bing' sweet cherry fruit. J. Amer. Soc. Hort. Sci. 107:151-154.

Green, C.J. 2001. Fibre in enteral nutrition. Clin. Nutr. 20:23-39.

Gross, J. 1991. Pigments in vegetables. chlorophylls and carotenoids. Van Nostrand Reinhold, New York.

Halilova, H. and S. Ercisli. 2010. Several physicochemical characteristics of cherry laurel (Laurocerasus officinalis Roem) fruits. Biotechnol. Biotechnol. Equip. 24(3):1970-1973.

Hendry, G.A. and J.D. Houghton. 1996. Natural food colourants, p. 348. Backie Academic and Professional, Glasgow. ISBN 0751402311 .

Islam, A. 2002. 'Kiraz' cherry laurel (Prunus laurocerasus). N. Z. J. Crop Hort. Sci. 30:301-302.

Karadeniz, T. and O. Kalkisim. 1996. Investigations on selection of cherry laurel (Prunus laurocerasus L.) grown in Akcaabat. J. YYU Agr. Fac. 6(1):147-153.

King, K. 1987. Method of rapid extraction of pectic substances from fruits. Food Chem. 8: 112-120.

Kolayli, S., M. Kucuk, C. Duran, F. Candan, and B. Dincer. 2003. Chemical and antioxidant properties of Laurocerasus officinalis Roem. (Cherry laurel) fruit grown in the Black Sea region. J. Agr. Food Chem. 51:7489-7494.

Landmark, K. and C.S. Alm. 2006. Alpha-linolenic acid, cardiovascular disease and sudden death. tidsskr. Nor. Laegeforen. 126:2792-2794.

Malik, S.S. and S.P. Singh. 2006. Role of plant genetic resources in sustainable agriculture. Indian J. Crop Sci. 1(1-2):21-28.

Mansour, A.M., R.K. Jila, and R.H. Sajedi. 2011. The comparison of protease activity and total protein in three cultivars of kiwifruit of Northern Iran during fruit development. Acta Physiol. Plant. 33(2):343-348.

Orhan, I.E. and E.K. Akkol. 2011. Estimation of neuroprotective effects of Laurocerasus officinalis Roem. (cherry laurel) by in vitro methods. Food Res. Int. 44:818-822.

Potter, N.N. and J.H. Hotchkiss. 1997. Food Science. 5th Ed. Food Science Texts. p. 608. Champan \& Hall.

Prior, R.L., G. Cao, A. Martin, E. Sofic, J. Mcewen, C. Obrien, N. Lischner, M. Ehlenfeldt, W. Kalt, G. Krewer, and C.M. Mainland. 1998. Antiox- idant capacity as influenced by total phenolic and anthocyanin content, maturity, and variety of Vaccinium species. J. Agr. Food Chem. 46: 2686-2693.

Reiser, S. 1987. Metabolic effects of dietary pectins related to human health. Food Technol. 41(2):91-99.

SAS Institute. 2005. SAS Online Doc., Version 8. SAS Institute Inc., Cary, NC.

Singleton, V.L. and J.L. Rossi. 1965. Colorimetry of total phenolics with phosphomolybdicphosphotungstic acid reagents. Amer. J. Enol. Viticult. 16:144-158.

Slinkard, K. and V.L. Singleton. 1977. Total phenol analyses: Automation and comparison with manual methods. Amer. J. Enol. Viticult. 28:49-55.

Socaciu, C. 2008. Chemical and functional properties of food components series, p. 617. Taylor \& Francis Goup, CRC Press.

Talcott, S.T. and L.R. Howard. 1999. Phenolic autoxidation is responsible for color degradation in processed carrot puree. J. Agr. Food Chem. 47:2109-2115.

Tall, J.M., N.P. Seeram, C. Zhao, M.G. Nair, R.A. Meyer, and S.N. Raja. 2004. Tart cherry anthocyanins suppress inflammation-induced pain behaviour in rat. Behav. Brain Res. 153: 181-188.

Tonucci, H.J., M.J. Holden, R.G. Beecher, F. Khachik, S.C. Davis, and G. Mulokozi. 1995. Carotenoid content of thermally processed tomato-based food products. J. Agr. Food Chem. 43:579-586.

Turkoglu, Z., S. Bilgener, S. Ercisli, M. Bakir, A. Koc, M. Akbulut, R. Gercekcioglu, M. Gunes, and A. Esitken. 2010. A. Simple sequence repeat-based assessment of genetic relationships among Prunus rootstocks. Genet. Mol. Res. 9(4):2156-2165.

Ustun, N.S. and I. Tosun. 2003. A research on composition of wild cherry laurel (Laurocerasus officinalis Roem.). J. Food Technol. 1:80-82.

Vavilov, N.I. 1951. The origin, variation, immunity and breeding of cultivated plants. Ronald, New York.

Wang, H., G. Cao, and R.L. Prior. 1996. Total antioxidant capacity of fruits. J. Agr. Food Chem. 44:701-705. 